\title{
Comment on: Occurrence of Vancomycin-Resistant Staphylococcus aureus (VRSA) in Clinical and Community Isolates with in the University of Port Harcourt
}

\author{
Hasan Cenk Mirza* \\ Department of Medical Microbiology, Başkent University, Faculty of Medicine, Turkey \\ Submission: March 07, 2019; Published: March 25, 2019 \\ *Corresponding author: Hasan Cenk Mirza, Department of Medical Microbiology, Bașkent University, Faculty of Medicine, 06790, Ankara, Turkey
}

Keywords: Vancomycin, S. aureus, Resistance, Vancomycin-resistant S. aureus, VRSA, MIC

Abbrevations: EUCAST: European Committee on Antimicrobial Susceptibility Testing; VRSA: Vancomycin-Resistant Staphylococcus aureus; CLSI:

Clinical and Laboratory Standards Institute

Sir,

I read with interest the article entitled 'Occurrence of Vancomycin-Resistant Staphylococcus aureus (VRSA) in clinical and community isolates within the university of Port Harcourt' [1]. The authors wanted to determine the prevalence of vancomycin-resistant $S$. aureus (VRSA) among 40 isolates of $S$. aureus. The authors used vancomycin disk diffusion method for the determination of VRSA. However, disk diffusion method is not reliable and should not be used for the determination of vancomycin resistance in $S$. aureus as well as coagulase negative staphylococci. Isolates of VRSA can be detected by vancomycin MIC testing [2].

Clinical and Laboratory Standards Institute (CLSI) has defined vancomycin MIC breakpoints for $S$. aureus as $\leq 2 \mu \mathrm{g}$ / $\mathrm{mL}$ (susceptible), $4-8 \mu \mathrm{g} / \mathrm{mL}$ (intermediate) and $\geq 16 \mu \mathrm{g} / \mathrm{mL}$ (resistant) [2]. The disk diffusion method with vancomycin was removed from the CLSI documents in 2009 because this method failed to distinguish vancomycin-susceptible strains from strains with vancomycin MIC of 4 to $16 \mu \mathrm{g} / \mathrm{mL}$ [3]. Also, European Committee on Antimicrobial Susceptibility Testing (EUCAST) does not recommend the use of disk diffusion method with vancomycin for staphylococci [4].

Isolates of VRSA are very rarely described worldwide [5,6]. The authors have not found any isolates of VRSA in their study [1].
There is a high probability of absence of VRSA among the isolates, but vancomycin MICs of all isolates should be determined to make a final decision.

\section{References}

1. Otobo U, Wala P, Agbagwa O (2018) Occurrence of VancomycinResistant Staphylococcus aureus (VRSA) in Clinical and Community Isolates Within the University of Port Harcout. Adv Biotech \& Micro. 11(4): 555816

2. (2018) Clinical and Laboratory Standards Institute Performance Standards for Antimicrobial Susceptibility Testing: Twenty-eighth Informational Supplement M100-S28, Wayne, PA: CLSI.

3. (2015) Clinical and Laboratory Standards Institute. Performance standards for antimicrobial disk susceptibility tests; approved standard-twelfth edition. Wayne (PA): CLSI, CLSI document M02-A12.

4. EUCAST. Breakpoint Tables for Interpretation of MICs and Zone Diameters, Version 9.0.

5. Mirza HC (2017) Glycopeptide resistance in S. aureus. In: Enany S, Alexander LE, (eds). The rise of virulence and antibiotic resistance in Staphylococcus aureus. In Tech Croatia, 43-59.

6. Melo-Cristino J, Resina C, Manuel V, Lito L, Ramirez M (2013) First case of infection with vancomycin-resistant Staphylococcus aureus in Europe. Lancet 382(9888): 205. 
This work is licensed under Creative Commons Attribution 4.0 Licens

DOI:10.19080/AIBM.2019.13.555861

\section{Your next submission with Juniper Publishers} will reach you the below assets

- Quality Editorial service

- Swift Peer Review

- Reprints availability

- E-prints Service

- Manuscript Podcast for convenient understanding

- Global attainment for your research

- Manuscript accessibility in different formats ( Pdf, E-pub, Full Text, Audio)

- Unceasing customer service

Track the below URL for one-step submission https://juniperpublishers.com/online-submission.php 